\title{
Characterization of Bacterial Populations in Urban and Rural Houston Watershed Soil Samples Following a Flooding Event
}

\author{
Folasade Tinuke Adedoyin ${ }^{1}$, Maruthi Sridhar Balaji Bhaskar², Jason Alan Rosenzweig 3, * \\ ${ }^{1}$ Department of Environmental and Interdisciplinary Science, Texas Southern University, Houston, the United States \\ ${ }^{2}$ Department of Earth and Environment Florida International University, Miami, the United States \\ ${ }^{3}$ Department of Biology Texas Southern University, Houston, the United States
}

Email address:

jason.rosenzweig@tsu.edu (J. A. Rosenzweig)

${ }^{*}$ Corresponding author

\section{To cite this article:}

Folasade Tinuke Adedoyin, Maruthi Sridhar Balaji Bhaskar, Jason Alan Rosenzweig. Characterization of Bacterial Populations in Urban and Rural Houston Watershed Soil Samples Following a Flooding Event. Frontiers in Environmental Microbiology.

Vol. 7, No. 1, 2021, pp. 22-34. doi: 10.11648/j.fem.20210701.14

Received: February 11, 2021; Accepted: February 24, 2021; Published: March 12, 2021

\begin{abstract}
Since Houston is prone to flooding events, bacterial population dynamics in Houston watershed soils pre- and postHurricane Harvey were evaluated. Unexpectedly, bayous closer to Houston's urban core, including Buffalo, Halls, Mustang, and Horsepen Bayous, had significantly higher enteric bacterial loads during the winter than the summer, likely due to water flow rate changes or proximity to wastewater outflow. Following bacterial load determination, isolated colonies were identified using biochemical tests. Additionally, metagenomic sequencing of 16S rDNA allowed for identification of both culturable and unculturable organisms. The phyla Proteobacteria, Actinobacteria, Bacteriodetes and Firmicutes were found to be dominant in our metagenomic analysis and are human gut bacteria. Some opportunistic bacterial Proteobacteria pathogens identified in our metabolomic analysis were Serratia marcenscens, Pseudomonas mendocina, Pseudomonas fulva, and Pseudomonas putida. To our knowledge, this is the first study that compares Houston-area bacterial populations before and after a major flooding event. Taken together, Hurricane Harvey likely contributed to a redistribution of enteric bacteria, as there was a significant increase in the enteric population of Buffalo and Halls Bayous. Similarly, our 2018 winter data set followed the same trend, as significant increases were seen in the enteric populations of Horsepen, Mustang, and Cypress Creek watershed soils.
\end{abstract}

Keywords: Enteric Bacteria, Environmental Isolates, Biochemical Analysis, Metagenomic, GIS

\section{Introduction}

Houston is popularly known as the "Bayou City," and its watersheds serve as recreational areas for residents. Recreationalists are at increased risk for exposure to bacterial contamination as well industrial contaminants bordering the shipping channel $[17,18,39]$. Wastewater outflows and agricultural runoff increase the load of microorganism in these various watersheds thereby posing a potential threat to human health $[2,6]$. According to the US Environmental Protection Agency (USEPA), watersheds are prone to bacterial contamination from natural and anthropogenic sources and are enhanced by urbanization, thereby leading to increased microbial populations). As a result, increased bacterial loads increase water turbidity, produce foul odor, and decrease dissolved oxygen [42]. Acceptable threshold limit cutoffs of Escherichia coli in Texas and other states begin at $126 \mathrm{cfu} / 100 \mathrm{ml}$ and for Enterococcus spp. lower thresholds begin at $33 \mathrm{cfu} / 100 \mathrm{ml}$ [48].

Previously, microbial loads and diversity in various water systems in Canada, Thailand, and the United States have been characterized [1, 33, 50, 56-58]. Further, Escherichia coli loads increased in the Squaw Creek watershed in Iowa and Beltsville, Maryland watershed following flooding events [3839, 45]. Additionally, a Canadian study revealed that both $E$. coli and Bacteriodes spp. loads were significantly increased in the Grand River watershed following a heavy rain event during the summer season [31]. Water flow rates can also affect 
microbial populations as well. Higher flow rates in Massachusetts watersheds during the winter season promoted bacterial loads variability and re-distribution from one location to another while low-flow rates were associated with the summer season [55]. More specifically, a two-day intense storm $(45 \mathrm{~mm} /$ day) led to higher $E$. coli loads than a light rainfall $(0-10 \mathrm{~mm} /$ day $)$ that lasted over a week in upper Blackstone River [59]. Additionally, after a major flooding event in Thailand, increases in Sulfuricurvum, Thiovirga, and Hydrogenophaga bacterial loads were recorded [28].

In Houston, Texas, urban watersheds like Dickinson, Buffalo, and White Oak Bayous, all near dense populations, tend to have elevated bacterial loads when compared to neighboring rural watersheds [5, 9]. More specifically, urban watersheds in Houston were found to have higher bacterial concentrations of $E$. coli and Enterococcus spp., and those elevations were influenced by rainfall events [9]. Reports evaluating Houston watershed bacterial loads $[5,9,40]$ have been published; however, to our knowledge, there have been no reports of bacterial loads in Houston watershed soil directly following flooding events. Soil harbors enormously diverse bacterial populations, and communities can vary greatly in composition $[4,16]$. Houston has recently experienced three significant flooding events in a three-year span from 2015- 2017 (i.e., the Memorial Day flooding, the tax-day flooding, and Hurricane Harvey). Such unprecedented flooding events warrant microbiological assessment of bacterial loads in Houston watershed soils to predict future redistribution and determine whether heavy rainfall events over short periods of time cause modifications therein.

In that vein, this study quantified bacterial loads for preHurricane Harvey (June 2017) and post-hurricane Harvey (November 2017) soil samples, as well as competitive samples from one year later [summer (June 2018) and winter (November) 2018]. We identified representative isolated colonies using ribotyping and biochemical analysis, assessed global bacterial population dynamics using meta-genomic sequence analysis, generated phylogenetic trees, and employed Geographic Information System (GIS) mapping of bacterial loads across various watershed.

\section{Materials and Methods}

\subsection{Study Areas}

The Halls Bayou begins in the northern part of Houston, Texas and flows for a $32 \mathrm{~km}$ length. It empties into Greens Bayou and also serves as recreational site for fishing for locals [21]. The Buffalo Bayou flows for approximately $85 \mathrm{~km}$, through Houston, and eventually into Galveston Bay and the Gulf of Mexico. It is a heavily urbanized watershed surrounded by $\sim 440,000$ people and has several tributary bayous (White Oaks, Greens, and Brays Bayous) flowing into it $[20,36$, 43]. Hunting Bayou originates in the northeast of Houston and flows into the Buffalo Bayou [22]. Based on the 2010 U.S. Census, the estimated population of the Hunting Bayou watershed is 75,908 and is highly urbanized with a mixture of residential, commercial, and industrial developments. Greens Bayou originates in northwest Houston and also flows into the Buffalo Bayou. The watershed covers about $549 \mathrm{~km}^{2}$ and includes several primary streams. There are about $495 \mathrm{~km}$ of open streams, including primary streams and tributary channels [20]. According to the 2010 U.S. Census, the estimated population of the Greens Bayou watershed is 528,720 . The White Oak Bayou flows from the southeast to its confluence with the Buffalo Bayou in downtown Houston. It has $234 \mathrm{~km}$ of open waterways, and based on the 2010 U.S. Census, the estimated population of the White Oak Bayou watershed is 433,250. Mustang Bayou originates in the northern part of Houston and is surrounded by mostly rural homesteads. It is serviced by a municipal collection system and wastewater treatment facility [19, 20, 25] Dickinson Bayou is a $33 \mathrm{~km}$-long, slow-moving, coastal stream that drains into Dickinson Bay, a subunit of the Galveston Bay system. Horsepen Bayou runs north of Clear Lake, Texas and east of Armand Bayou. It has a wastewater treatment plant located adjacent to it $[23,24,41,47]$. Finally, Cypress Creek Bayou drains into an area of $495 \mathrm{~km}^{2}$ and lies in the northern part of Houston surrounded by rural farmland [7, 46]. It is a major source of drinking water and a contributor of pollutant and urban runoff into Lake Houston [7, 44].

\subsection{Sample Collection and Processing}

Rural and suburban watershed areas with accessible locations for soil sampling were identified using the Geographic Information Systems (GIS) (ArcMap 10.3, ESRI Inc.). Watershed soil was sampled in both summer and fall of 2017 (Figure 1) and of 2018 (Figure 2). In short, 0-10 cm of surface soil along the bayou flood plain was collected from all watersheds in this study using a trowel and a probe. Samples of $100 \mathrm{~g}$ were placed in zip lock bags and stored at $4{ }^{\circ} \mathrm{C}$ within $6 \mathrm{hr}$. A total of 36 surface soil samples were collected from 12 locations spread over 5 watersheds during the summer (June, $29.4^{\circ} \mathrm{C}$ ) and winter (November, $13.8^{\circ} \mathrm{C}$ ) of 2017 while a total of 92 surface soil samples were collected from 14 locations spread over 5 watersheds during summer (June, $28.3^{\circ} \mathrm{C}$ ) and winter (November, $12.2^{\circ} \mathrm{C}$ ) of 2018 .

All samples were collected in triplicate. Soil samples were collected from G58.4, G50, and G49.4 and G6.1 location along Greens Bayou, B29.5 along Buffalo Bayou, HU20.7 along Hunting Bayou, HA28.5, HA24.7, and HA6.1 along Halls Bayou, W019.8, WO1.7, W00.1 along White Oak Bayou during 2017. During 2018 samples were collected from CC58.1, CC49.2 and CC28.5 along Cypress Creek, MB56, MB48.8, and MB22.6 along Mustang Bayou, DKB 12, DKB9.4 and DKB0.1 along Dickinson Bayou, and HB9.9, HB3.1 and HB0.1 along Horsepen Bayou. The sample locations were named with a letter followed by a number, where the letters stand for the name of the bayou and the number represents the distance of the sample site (in $\mathrm{km}$ ) from the mouth of the Bayou. For example, G58.4 represents the sample site located at $58.4 \mathrm{~km}$ from mouth of the Greens Bayou. A modified version of a sample processing protocol [49] was used. In short, soil samples were dried at room 
temperature for $16 \mathrm{hr}$. An amount of $1 \mathrm{~g}$ of dry soil was suspended in $10 \mathrm{ml}$ of deionized water and was vigorously agitated to disrupt soil aggregates; agitation periods varied from $10 \mathrm{~min}$ to $1 \mathrm{hr}$. depending on need and different soil types. 10 -fold serial dilutions were prepared in $1 \mathrm{ml}$ volumes ranging from $10^{0}-10^{-7}$.

\subsection{Bacterial Enumeration}

A modification of a previously published protocol [49] was employed. The broad medium Luria Bertani (LB) agar (BD Difco $^{\text {TM}}$ ) was used to cultivate total loads while the selective and differential medium, MacConkey agar (Difco $\left.{ }^{\circledR}\right)$, was used to enrich for enteric bacteria. Media was prepared (per manufacturer's specification) and were then autoclavesterilized at $121^{\circ} \mathrm{C}$ for $30 \mathrm{~min}$. Either 100 or $33 \mu \mathrm{l}$ of soil suspension dilutions (described above) were aseptically plated in triplicate, spread on both MacConkey and LB media, and incubated at either 32 or $37^{\circ} \mathrm{C}$ for $18 \mathrm{hr}$. Colonies were then enumerated by plate counting. Bacterial concentrations are typically reported in $\mathrm{cfu} / \mathrm{ml}$; however, we have reported concentrations in $\mathrm{cfu} / \mathrm{g}$.

\subsection{Bacterial Isolation and Characterization}

Twelve representative down-selected colonies from both LB and MacConkey plates were isolated and subjected to Gram-staining, catalase, and oxidase tests. For Gram-staining, smears of isolates were prepared on glass slides, heat-fixed, and flooded with crystal violet for $1 \mathrm{~min}$, Gram's iodine for 1 min, de-colorizer for $15 \mathrm{sec}$, and then the counter-stained with safranin for $1 \mathrm{~min}$. For the catalase test, a drop of $3 \%$ $\mathrm{H}_{2} \mathrm{O}_{2}$ was added to bacterial smears, and positive results were indicated by gaseous $\mathrm{O}_{2}$ bubble formation. Oxidase tests employed a colorless oxidase reagent (BD oxidase reagent dropper catalog \#261181), and positive results were scored by a purple color gain.

\subsection{BIOLOG Microstation Colony Identification}

The 12 down-selected colony isolates (at least one from each watershed) were then identified by the Biolog GEN III identification system (Biolog, Hayward, CA, USA), according to the manufacturer's protocol. In summary, pure bacterial cultures were suspended in an inoculating fluid (IF-A GEN III Cat \#: 72401$)$ to a specified density $\left(\sim 0.2 \mathrm{OD}_{600 \mathrm{~nm}}\right)$ using the turbidity meter (Biolog TM). Bacterial suspensions $(100 \mu \mathrm{l})$ were pipetted into each well of the micro-plate (GEN III Cat \#: 1030) and incubated at temperatures of either $37^{\circ} \mathrm{C}$ for enterics or $32^{\circ} \mathrm{C}$ for environmental isolates for a minimum of $24 \mathrm{hr}$. The micro-plate was then read with the Biolog Micro Station system and compared to the database for the purpose of organism species identification.

\subsection{Metagenomics Analysis}

Soil (5 g) from the Halls Bayou watershed (29.9101480 N 95.4462770 W) was shipped to MR DNA (Shallowater, Texas) where DNA extractions, purifications were carried out. DNA was extracted using the DNeasy PowerSoil Kit (Qiagen). Solid samples $(250 \mathrm{mg})$ were used to extract the DNA. Pellets were re-suspended in $100 \mu \mathrm{l}$ water and used for extraction. DNA quantity and quality was determined using NanoDrop2000 (Thermo Scientific). Samples were then used to quantify the bacterial concentrations by $\mathrm{qPCR}$ using Bacteria2F and Bacteria2R primers [13]. Template DNA $(1 \mu \mathrm{l})$ was used to perform the qPCR reactions using $2 \mathrm{X}$ Universal Taqman PCR Mastermix (Applied Biosystems) in StepOnePlus Real-Time PCR System (Applied Biosystems). Three replications were used for each sample. DNA from $E$. coli was used as standard. More specifically, 16S rRNA gene V4 variable region PCR primers 515/806 (barcoded on the forward primer) were used in a 30 cycle PCR using the HotStarTaq Plus Master Mix Kit (Qiagen, USA) using the following conditions:

$94^{\circ} \mathrm{C}$ for $3 \mathrm{~min}$, followed by 30 cycles of $94^{\circ} \mathrm{C}$ for $30 \mathrm{sec}$, $53^{\circ} \mathrm{C}$ for $40 \mathrm{sec}$, and $72^{\circ} \mathrm{C}$ for $1 \mathrm{~min}$, proceeded by a final elongation at $72^{\circ} \mathrm{C}$ for $5 \mathrm{~min}$. Following amplification, PCR products were evaluated in a $2 \%$ agarose gel for quality control and to determine relative band intensities. Multiple samples were pooled together and purified with Ampure XP beads (e.g., 100 samples) in equal proportions based on their molecular weight and DNA concentrations. Pooled and purified PCR products were then used to prepare Illumina DNA libraries.

Sequencing was also performed at MR DNA (Shallowater, TX, USA) on a MiSeq (Illunima Inc.) following the manufacturer's guidelines. Sequence data were processed using MR DNA analysis pipeline and Qiime. In summary, sequences were joined and depleted of barcodes and primers. Then, sequences $<150 \mathrm{bp}$ were removed, and sequences with ambiguous base calls were removed. Operational taxonomic units (OTUs) were defined by clustering at 3\% divergence (97\% similarity) while controlling for chimeras. Final OTUs were taxonomically classified using BLASTn against RDPII and NCBI databases (http://www.ncbi.nlm.nih.gov, http://rdp.cme.msu.edu). Metagenomic data was submitted to NCBI as a sequence read archive (SRA) with accession numbers STUDY: PRJNA670738

SAMPLE: HBS17 (SAMN16519721)

EXPERIMENT: HBS17 (SRX9348736) RUN: Sam14_S9_L001_R1_001.fastq (SRR12882787).

\subsection{Molecular CFU Counts}

DNA was extracted using the DNeasy PowerSoil Kit (Qiagen). Solid samples (250 mg) were used for DNA extraction. Pellets were re-suspended in $100 \mu \mathrm{l}$ water and used for extraction. DNA quantity and quality was determined using NanoDrop2000 (Thermo Scientific). Samples were then used to quantify bacterial concentrations by $\mathrm{qPCR}$ using Bacteria2F and Bacteria2R primers. Template DNA (1ul) was used for qPCR reactions together with 2XUniversal Taqman PCR Mastermix (Applied Biosystems) in StepOnePlus Real-Time PCR System (Applied Biosystems). Three replications were used for each sample. DNA from $E$. coli was used as a standard. 


\subsection{Geography Information System (GIS) Mapping}

The bayou flow lines, watershed boundary and the flood hazard layers were extracted from the National Flood Hazard Layer (NFHL) database (https://www.floodmaps.fema.gov/NFHL/status.shtml) and Houston-Galveston Area Council GIS datasets (http://www.h-gac.com/gis-applications-and-

data/datasets.aspx). Soil sampling points of the study areas were imported into GIS as separate vector layer. The data were downloaded and processed using the ArcGIS Version 10.5 software $[12,54]$.

\subsection{Statistical Analysis}

All experiments were carried out in triplicate and averaged. Statistical analysis of the data was done using Microsoft Excel. The Student's two-tailed T-test (unequal variance) was used to derive p-values. Significant differences were considered with $p$-values less than or equal to $0.01(* *)$ or $p$ values $\leq$ to $0.05(*)$.

\section{Results}

In an attempt to determine whether Hurricane Harvey influenced total and enteric bacterial loads in watershed soils with high numbers of wastewater treatment facilities and superfund sites, we evaluated soil samples from 2017 (before and after Hurricane Harvey) (Figure 1) and one year later in 2018 (Figure 2). Over the course of our one-year study, we observed bayous fed by over 90 wastewater outflows such as Greens (2017), Dickinson (2018), Cypress Creek (2018) and Buffalo Bayous (2017) (Table 1; Figures 1-4). In 2017, we observed significantly higher total bacterial populations in 3 out of our 4 Greens Bayou locations ( $<<0.01)$, 1 out of our 3 Halls Bayou locations $(\mathrm{p}<0.01)$, and our one Buffalo Bayou location $(\mathrm{p}<0.001)$ when comparing pre-Hurricane Harvey (summer) to post-Hurricane Harvey (winter) (Figure 3a). Surprisingly, 1 of 4 Greens Bayou locations, G49.4 conversely reported 1.4 -fold significantly lower $(p<0.01)$ total pre-Harvey bacterial loads $\left(2.5 \times 10^{6} \mathrm{cfu} / \mathrm{g}\right)$ relative to post-Harvey loads $\left(3.5 \times 10^{6} \mathrm{cfu} / \mathrm{g}\right)$ (Figure $3 \mathrm{~A}$ ) for reasons unexplained. In that same vein, 2 of 3 Halls Bayou locations similarly had bacterial loads that were significantly lower (5.5- and 7.4-fold, respectively) during pre-Harvey (summer) when compared to post-Harvey (winter) (Figure 3A). Overall, significant differences (higher or lower) were observed in 3 of 4 bayou soil samples being evaluated (Figure 1) when comparing total pre-Harvey to post-Harvey loads. The sole exception was White Oak Bayou, for which no significant differences were observed when comparing pre-Harvey to post-Harvey total bacterial loads at any of the 3 locations evaluated (Figure 3A).

Beyond evaluating total bacterial loads, we sought to determine whether changes in enteric bacterial loads were prompted by the Hurricane Harvey flooding event, on account of many enteric bacteria being either opportunistic or bona fide pathogens. Mirroring what we observed for total bacterial loads (Figure 3A), none of the three White Oaks Bayou soil samples exhibited statistically significant difference between pre- and post-Harvey enteric loads (Figure 3B). Of the three Halls Bayou sites examined, only 2 of 3 sites (HA24.7 and HA28.5) exhibited 3.1- and 12.4-fold significantly lower, respectively, pre-Harvey enteric loads $\left(1.5 \times 10^{5} \mathrm{cfu} / \mathrm{g}\right.$ and $\left.7.7 \times 10^{4} \mathrm{cfu} / \mathrm{g}\right)$ compared to the postHarvey enteric load $\left(4.9 \times 10^{5} \mathrm{cfu} / \mathrm{g}\right.$ and $\left.9.4 \times 10^{5} \mathrm{cfu} / \mathrm{g}\right)$ (Figure 3B). We observed that our enteric bacterial values were above the EPA [51-53] and Texas Commission on Environmental Quality (TCEQ) thresholds (104 - 575 $\mathrm{cfu} / 100 \mathrm{ml}$ ). Despite our one Buffalo Bayou soil sample site having a significantly higher total bacteria pre-Harvey load (Figure 3A), in sharp contrast, the enteric bacterial load was 14.2-fold significantly lower $(\mathrm{p}<0.05)$ when comparing those same two time points (Figure 3B). More specifically, the preHarvey enteric load for our Buffalo Bayou soil sample was $5.6 \times 10^{3} \mathrm{cfu} / \mathrm{g}$ (below the EPA threshold) compared to the $6.0 \times 10^{4} \mathrm{cfu} / \mathrm{g}$ post-Harvey level, exceeding the EPA threshold (Figure 3B). Largely in agreement with what we observed for total bacterial loads (Figure 3A), 3 of 4 Greens Bayou (G49.4, G50, and G58.4) enteric loads were 1.3-, 7.6-, and 31-fold significantly higher in pre-Harvey samples relative to post-Harvey samples (Figure 3B). More specifically, Greens Bayou G49.4, G50, and G58.4 preHarvey enteric loads were $1.1 \times 10^{5} \mathrm{cfu} / \mathrm{g}, 5.5 \times 10^{5} \mathrm{cfu} / \mathrm{g}$, $1.1 \times 10^{6} \mathrm{cfu} / \mathrm{g}$ compared to $8.1 \times 10^{4} \mathrm{cfu} / \mathrm{g}, 7.2 \times 10^{4} \mathrm{cfu} / \mathrm{g}$, and $3.6 \times 10^{5} \mathrm{cfu} / \mathrm{g}$ post-Harvey loads respectively (Figure 3B). The aforementioned post-Harvey Green's Bayou soil loads all exceeded EPA and/or TCEQ threshold water limits.

When evaluating bayou soil samples for both total and enteric bacterial loads one year following the Hurricane Harvey flooding event, we chose to evaluate sites that were either in a less dense region of Greater Houston (Cypress Creek Bayou) or further south of Houston (Horsepen, Mustang and Dickinson Bayous) to where bacteria may have been redistributed following the flood (Figure 2).

With regards to total bacterial loads, 2 of the 3 Horsepen Bayous evaluated were 1.9- and 1.2-fold significantly higher post-Harvey relative to pre-Harvey measures (Figure 4A). Only 1 of the 3 Dickinson Bayou samples (DB9.4) exhibited a 2.59-fold significantly higher summer load relative to winter (Figure 4A). Similarly, only 1 of our 3 Mustang Bayou (MB56) sample sites revealed a significant difference in total bacterial load; however, the 1.4-fold significantly higher difference was in post-Harvey total load compared to its pre-Harvey counterpart (Figure 4A). Unlike the abovementioned bayous evaluated in 2018, the Cypress Creek Bayou revealed significant differences, although not entirely consistent, in all three of our sample sites. More specifically, 2 of the 3 (CC58.1 and CC28.5) revealed 3.49- and 1.9-fold significantly higher total bacterial loads post-Harvey compared to pre-Harvey (Figure 4A). Interestingly, CC49.2 exhibited a 1.4-fold significantly higher total pre-Harvey load $\left(4.1 \times 10^{7} \mathrm{cfu} / \mathrm{g}\right)$ compared to the corresponding post-Harvey load $\left(2.7 \times 10^{7} \mathrm{cfu} / \mathrm{g}\right)$ (Figure $\left.4 \mathrm{~A}\right)$.

When we evaluated enteric bacterial loads at our 2018 sites, 
only one of the Horsepen Bayou samples (HB3.1) had a 1.49fold significantly higher post-Harvey load compared to preHarvey (Figure 4B). Similarly, only one of the three Dickinson Bayou samples (DB9.4) exhibited a 5.3-fold significantly higher pre-Harvey load $\left(3.4 \times 10^{6} \mathrm{cfu} / \mathrm{g}\right)$ compared to postHarvey $\left(1.9 \times 10^{6} \mathrm{cfu} / \mathrm{g}\right)$ (Figure 4B). All 3 of the Mustang Bayou samples similarly had 2.3-, 4.3-, and 5.3-fold significantly higher post-Harvey enteric loads compared to their pre-Harvey counterparts (Figure 4B). Finally, mirroring the Mustang Bayou enteric load data, all 3 of the Cypress Creek Bayou samples similarly had 2.0-, 19.5-, and 13.5-fold significantly higher post-Harvey enteric loads compared to their summer counterparts (Figure 4B), all above EPA and TCEQ threshold water limits. Soil levels tend to be higher because of accumulation.

From our total and enteric loads, 12 down-selected representative colonies were selected for further characterization and identification (Table 2). Using the BIOLOG Microstation, we identified 10 Gram-negative bacteria on both broad- and selective-media including: Serratia marcescens, Routella planticola, Pseudomonas fulva, Pseudomnas putida, Pseudomonas pertucinogena, Pseudomonas mendocina, Pseudomonas taetrolens, Acinetobacter soil, Shewanella algae, and Delftia tsuruhatensis as well as 2 Gram-positive organisms: Bacillus cibi and Sporosarcina aquimarina (Table 2).

In efforts of achieving a more comprehensive assessment of bacterial population dynamics and diversity in our soil samples, we undertook a global metagenomic approach to compare population dynamics of our Halls Bayou preHarvey (Figure 5A) and post-Harvey (Figure 5B) 2017 pooled samples. In both the 2017 samples, the Proteobacteria (which include a number of pathogenic and non-pathogenic Gram-negative bacteria) represented the largest percentage operational taxonomic unit phylum, 53\% and $51 \%$, respectively (Figure 5). This is in agreement with the 10 of 12 Gram-negative bacteria that we isolated from the multiple bayous we examined, including Halls Bayou (Figure 3). In fact, the majority of Gram-negative isolates (Table 2) were pseudomonads which all fall under the phylum Proteobacteria. The remaining 9 phyla, including the Firmicutes and their large number of Gram-positive bacteria, compared had very similar percent distribution of operational taxonimc units in both 2017 samples (Figure 5). These data suggest that despite an unprecedented flooding event, the population dynamics at the phyla level did not change much within Halls Bayou (Figure 5). When examining sequence counts at the species level in both 2017 samples of 24 species, including the pathogenic Burkholderia spp., we observed a 2.69-fold increase in post-Harvey sequence counts (Figure 6). Similarly, we observed a 2.0-fold increase in Pseudomonas spp. in the post-Harvey counts as well. Taken together, these data suggest that although population dynamics at the phylalevel may not change dramatically following a flooding event (Figure 5), changes could occur at the species-level (Figure 6) promoting the expansion of disease-causing pathogens.

Table 1. Pollution sources in Houston area watershed soil samples. The soil types in all the watershed include clay, sandy, and loamy. The highest wastewater discharge is seen in Buffalo Bayou followed by Cypress Creek. No superfund site is seen in Cypress Creek watershed in addition to the lowest enteric counts recorded in this watershed.

\begin{tabular}{|c|c|c|c|}
\hline Watershed & Soil type & Wastewater discharge & Pollution sources \\
\hline Greens & Clay and silt, locally sandy & $\begin{array}{l}\text { Over } 95 \text { million gallons per } \\
\text { day (domestic) } \\
\text { Approximately } 300 \text { total } \\
\text { outfalls (domestic and } \\
\text { industrial) }\end{array}$ & Wastewater outfall. Municipal solid waste sites, superfund sites \\
\hline White oaks & $\begin{array}{l}\text { Generally clay loam, silty clay } \\
\text { loam, sandy clay, silty clay, or clay } \\
\text { with very low infiltration potential }\end{array}$ & $\begin{array}{l}\text { Approximately } 49 \text { total } \\
\text { outfalls }\end{array}$ & $\begin{array}{l}\text { Wastewater outfall, construction, agriculture, } \\
\text { industrial/commercial. Mining, golf courses and waterways }\end{array}$ \\
\hline Buffalo & Clay & 183 & $\begin{array}{l}\text { Wastewater outfall. Municipal solid waste sites, superfund sites, } \\
\text { recreational activities }\end{array}$ \\
\hline Dickinson & $\begin{array}{l}\text { Generally clay loam, silty clay } \\
\text { loam, sandy clay, silty clay, or clay } \\
\text { with very low infiltration potential }\end{array}$ & 92 & $\begin{array}{l}\text { Wastewater outfall. Municipal solid waste sites, superfund sites, } \\
\text { recreational activities }\end{array}$ \\
\hline Mustang & Sandy and loamy & 43 & Wastewater outfall. Municipal solid waste sites, superfund sites \\
\hline Halls & Silt, sandy and clay & 47 & Wastewater outfall, sanitary sewer outflow, sewage facilities \\
\hline Hunting & Mixture of clay and loamy & 9 & Wastewater outfall, pets, sanitary sewer outflows, storm water. \\
\hline Horsepen & Clay loam & Not reported & Storm water, human and pets discharge, construction sites \\
\hline Cypress creek & Silty, clay loamy & 99 & Wastewater outfall. Municipal solid waste sites \\
\hline
\end{tabular}

Table 2. Morphology and Biochemical test of isolated unknowns. Environmental isolates were identified through Gram staining, biochemical reactions, and the BIOLOG Microstation.

\begin{tabular}{|c|c|c|c|c|c|c|}
\hline Colony/Morphology & Environmental source & Medium & Gram test & Oxidase test & Catalase test & Biolog identification \\
\hline UK1/Red & Buffalo Bayou & $\mathrm{M}$ & - & - & + & Serratia marcescens \\
\hline UK2/Cream & Dickinson Bayou & LB & - & - & + & Raoutella planticola \\
\hline UK3/Yellow & Buffalo Bayou & LB & - & - & + & Pseudomonas fulva \\
\hline UK4/Yellow & Halls Bayou & LB & - & - & + & Pseudomonas putida \\
\hline UK5/Orange & Greens Bayou & LB & $\overline{+}$ & $\overline{+}$ & _ & Bacillus cibi \\
\hline UK6/Cream & White oaks Bayou & M & & & $\overline{+}$ & Pseudomonas pertucinogena \\
\hline
\end{tabular}




\begin{tabular}{lllllll}
\hline Colony/Morphology & Environmental source & Medium & Gram test & Oxidase test & Catalase test & Biolog identification \\
\hline UK7/Orange & White oaks Bayou & LB & + & + & + & Sporosarcina aquimarina \\
UK8/Cream & Horsepen watershed & M & - & - & + & Pseudomonas mendocina \\
UK9/Cream & Horsepen watershed & LB & - & - & + & Pseudomonas taetrolens \\
UK10/pale yellow & Horsepen watershed & M & - & - & + & Acinetobacter soli \\
UK11/Pink & Hunting watershed & M & - & - & + & Shewanella algae \\
UK12/White & Cypress Creek watershed & LB & - & + & + & Delftia tsuruhatensis \\
\hline
\end{tabular}

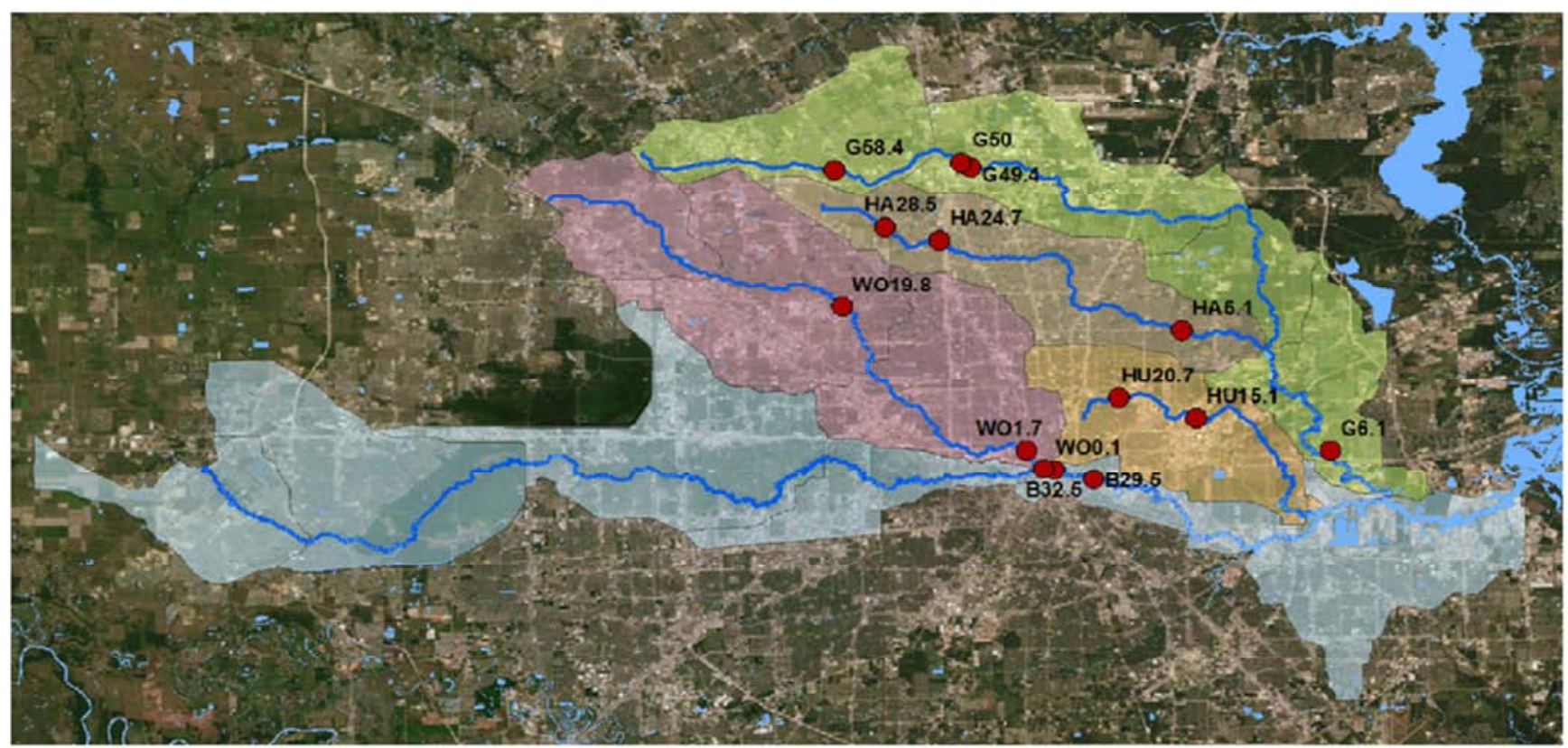

Figure 1. Soil samples for bacterial analysis were collected in triplicate from various sites in the Greens, Halls, Hunting, White Oak, and Buffalo Bayous during the summer and fall of 2017. Location of soil samples, G6.1, G49.4, G50 and G58.4 along Greens Bayou; HA6.1, HA24.7 and HA28.5 along Halls Bayou; HU15.1 and HU20.7 along Hunting Bayou; WO0.1, WO1.7 and WO19.8 along the White Oak Bayou and B29.5 and B32.5 along Buffalo Bayou are shown in the image.

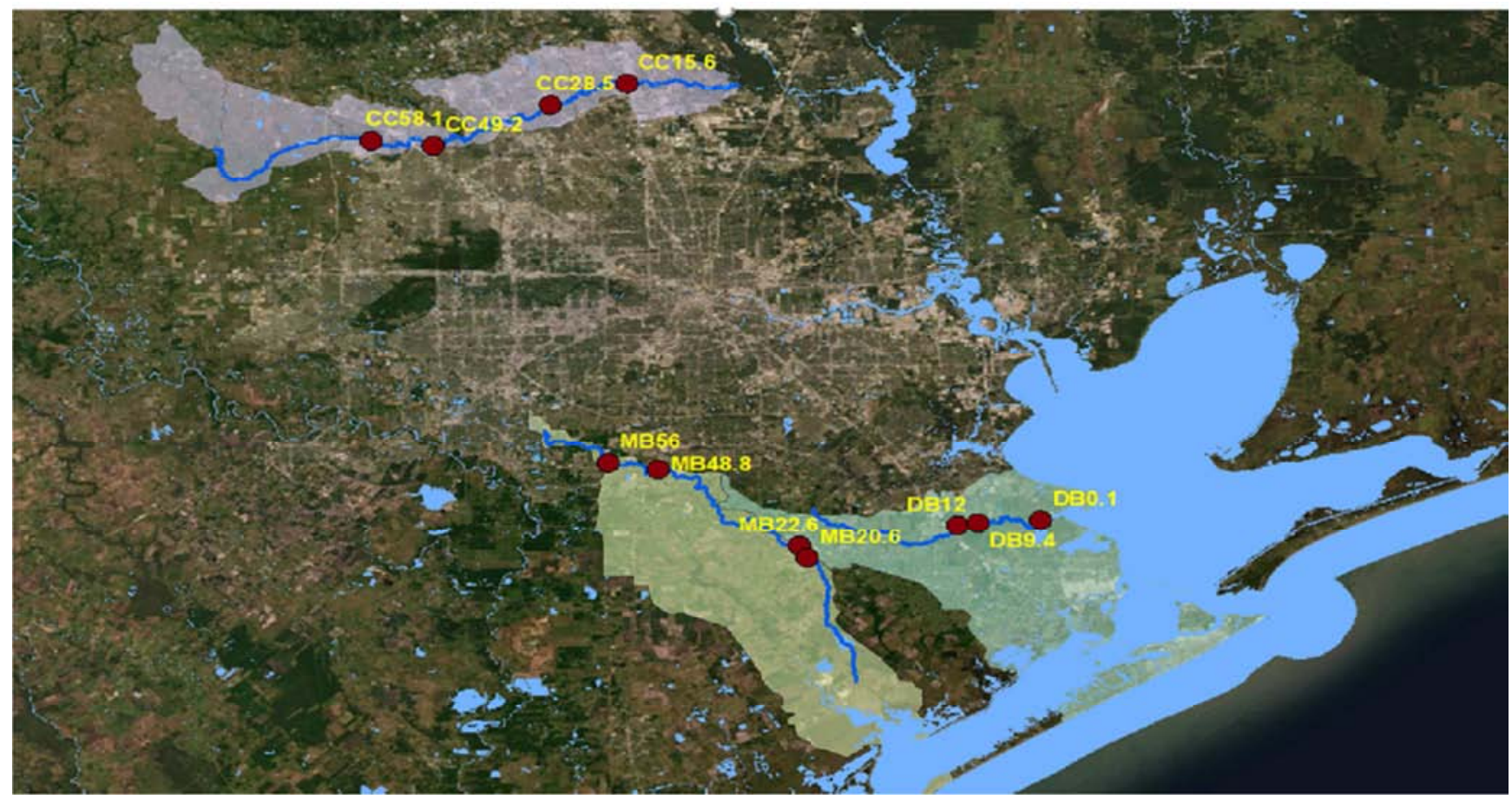

Figure 2. Soil samples for bacterial analysis were collected in triplicate from various sites in the Cypress Creek, Dickinson, Horsepen, and Mustang Bayous during the summer and fall of 2018. Location of soil samples, CC15.6, CC28.5, CC49.2, and CC58.1 along Cypress Creek; DB0.1, DB9.4, and DB12 along Dickinson Bayou, MB20.6, MB22.6, MB48.8, and MB56 along Mustang Bayou are shown in the image. 


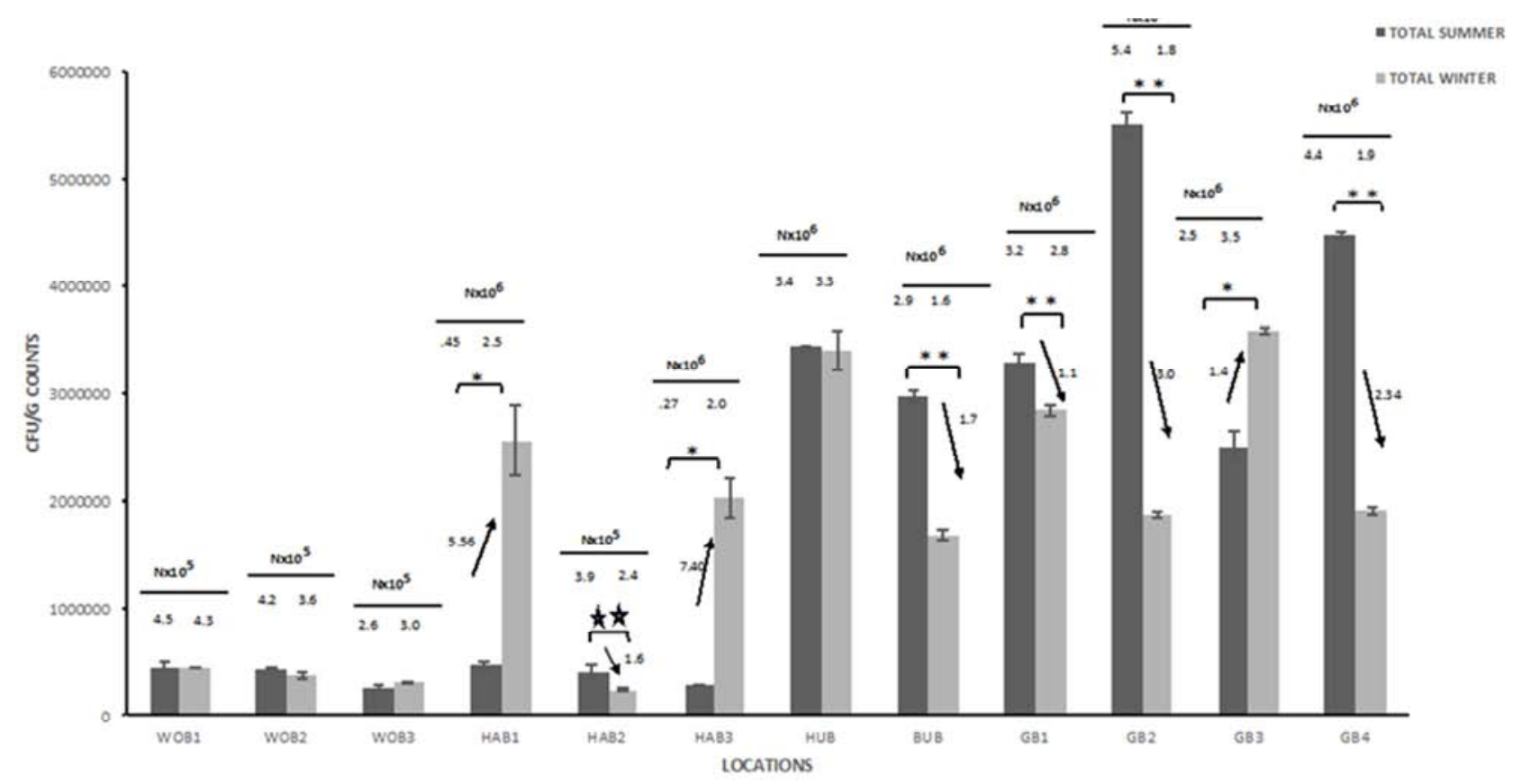

$\mathrm{P}<0.05$ :

$\mathrm{P}<0.01$ :

(a)

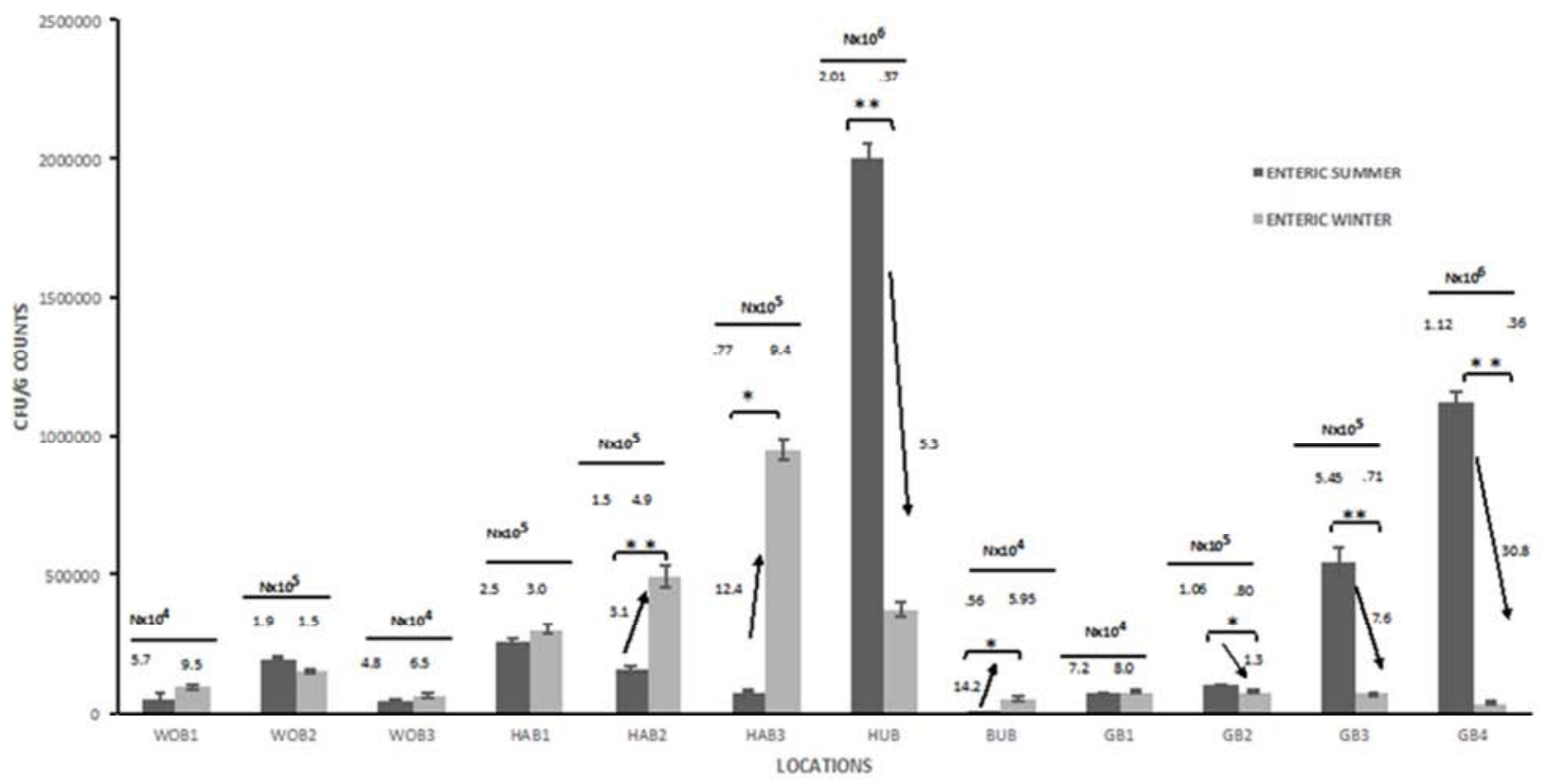

$\mathrm{P}<0.05$ * $^{*}$

$\mathrm{P}<0.01$ : **

(b)

Figure 3. Total and enteric bacterial counts for the 2017 study sites. The five watersheds sampled in 2017 summer (A) and winter (B) were Greens, Halls, Hunting, Buffalo, and White Oaks Bayous. This experiment was run in triplicate and statistical analysis was determined using the Student's T-test, with $p<$ 0.05 denoted by one asterisk and $p<0.01$ denoted by two asterisks. 


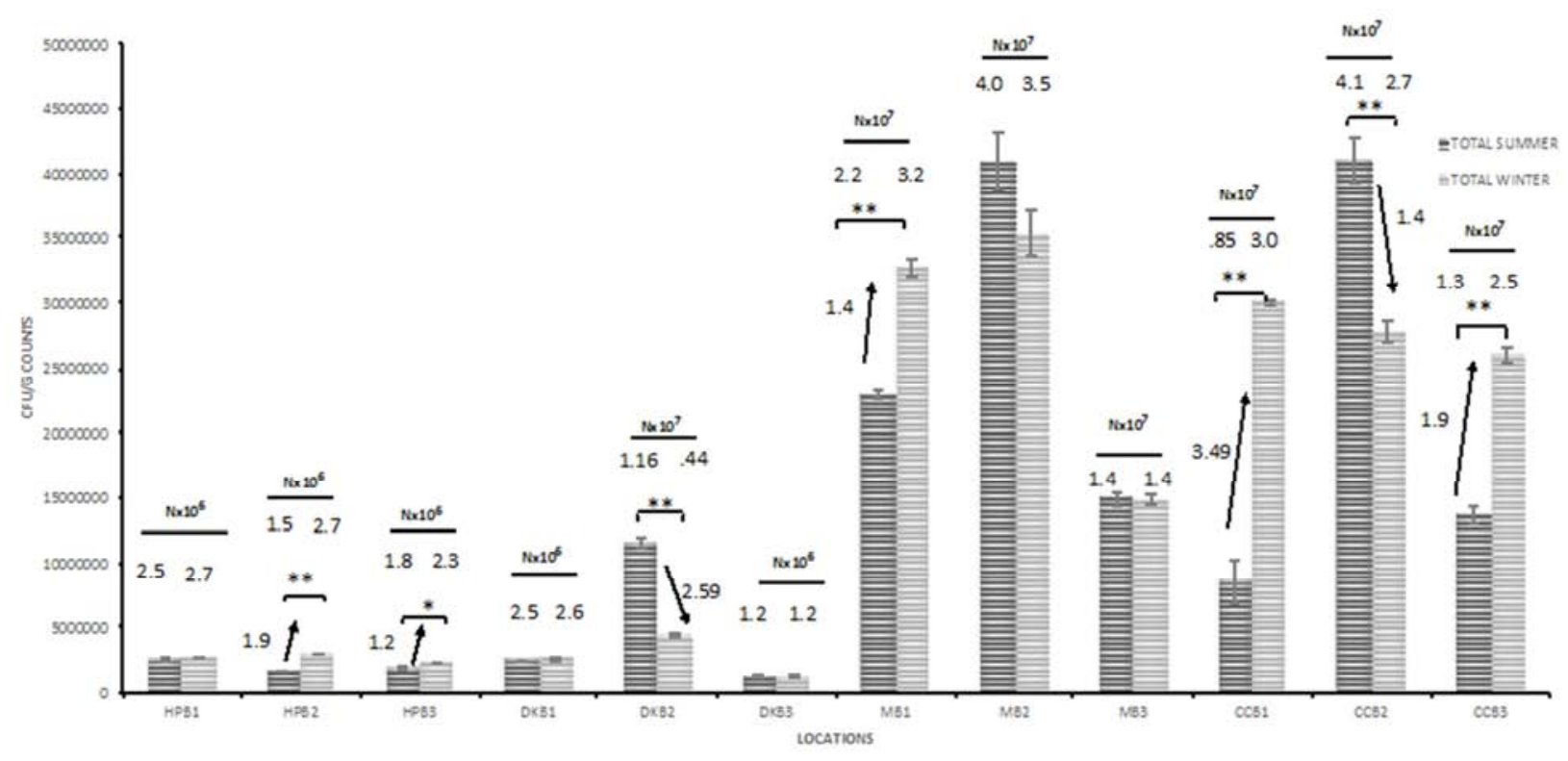

$\mathrm{P}<0.05:$ *

$\mathrm{P}<0.01$ : *

(a)

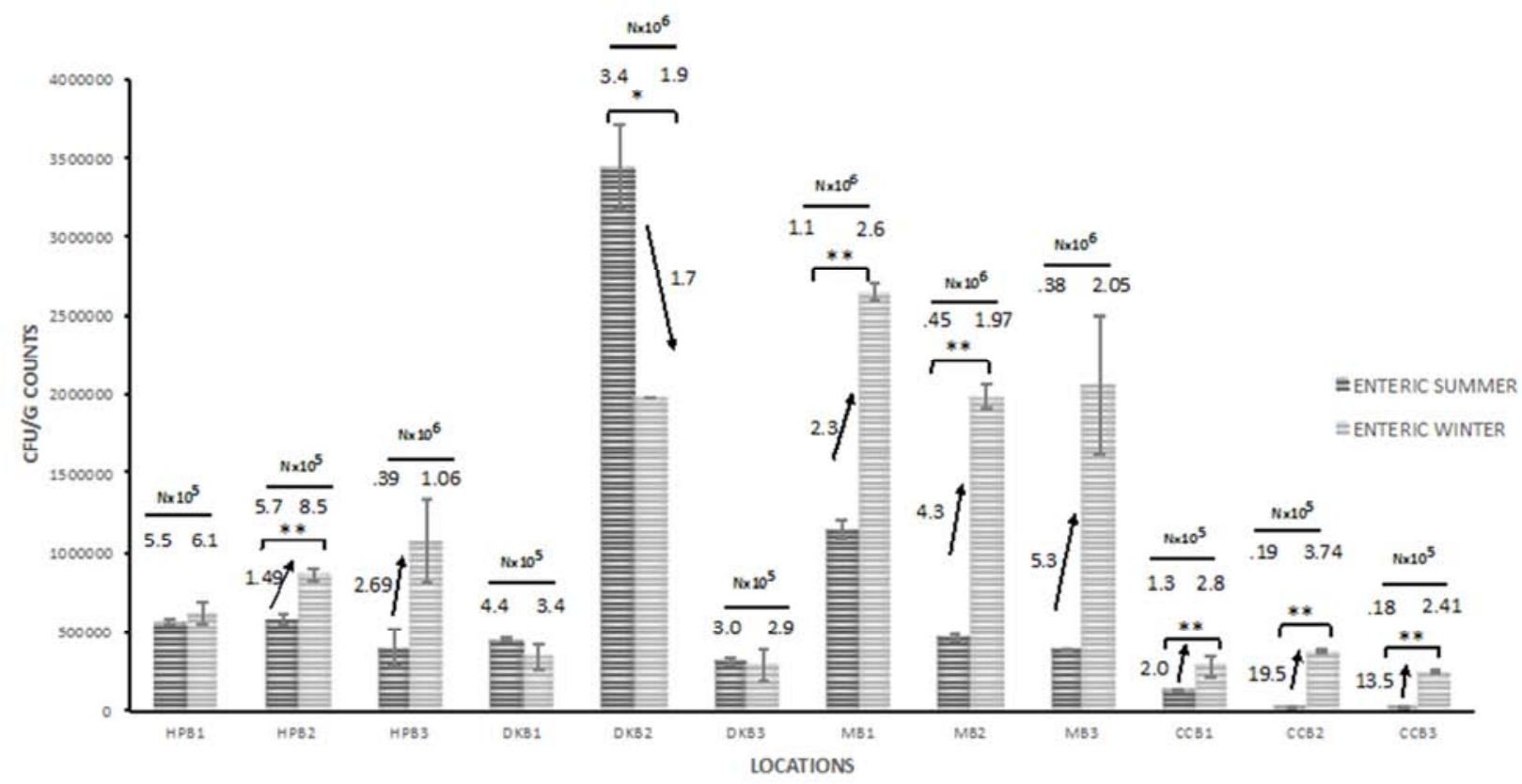

$\mathrm{P}<0.05: *$

$\mathrm{P}<0.01$ : $^{*}$

(b)

Figure 4. Total and enteric bacterial counts for the 2018 study sites. The four watersheds sampled in 2018 summer (A) and winter (B) were Horsepen, Dickinson, Mustang, and Cypress Creek Bayous. This experiment was run in triplicate and statistical analysis was determined using the Student's T-test, with $p$ $<0.05$ denoted by one asterisk and $p<0.01$ denoted by two asterisks. 

Watershed Soil Samples Following a Flooding Event
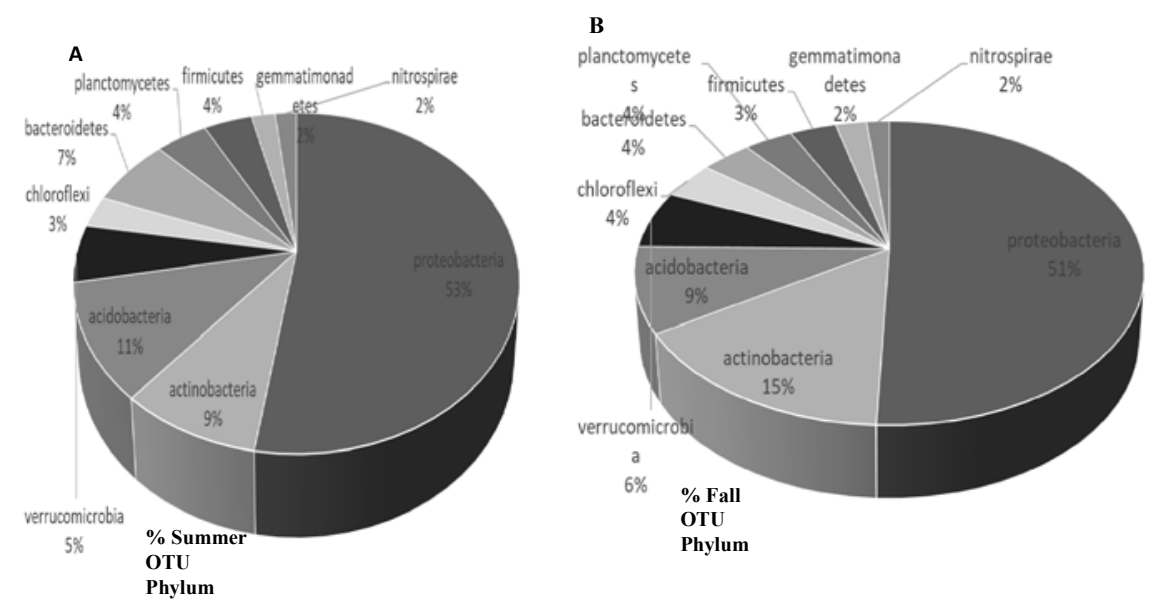

Figure 5. (

The four $p$

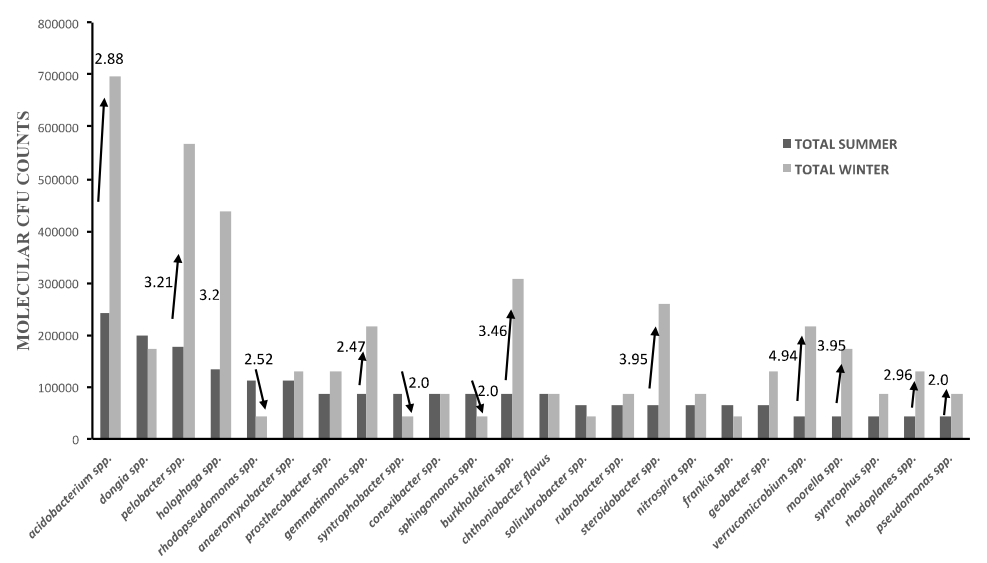

ESTIMATED copies BACTERIA

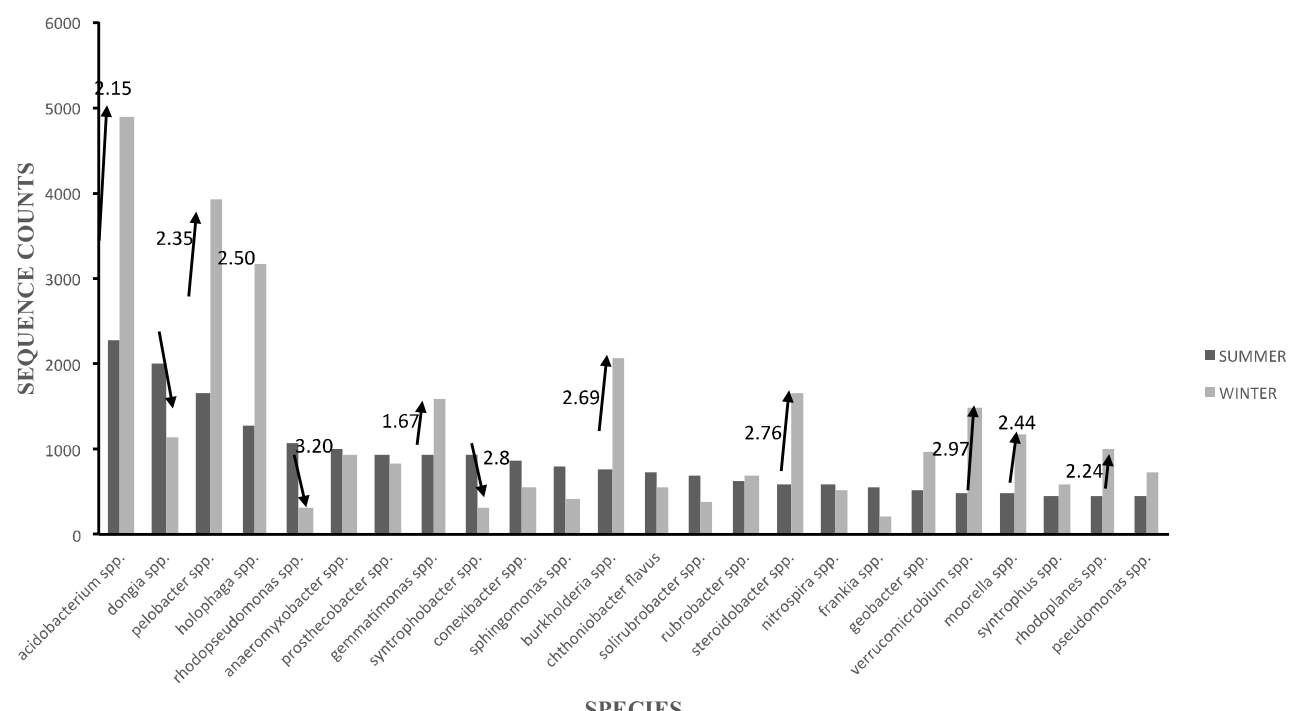

SPECIES 

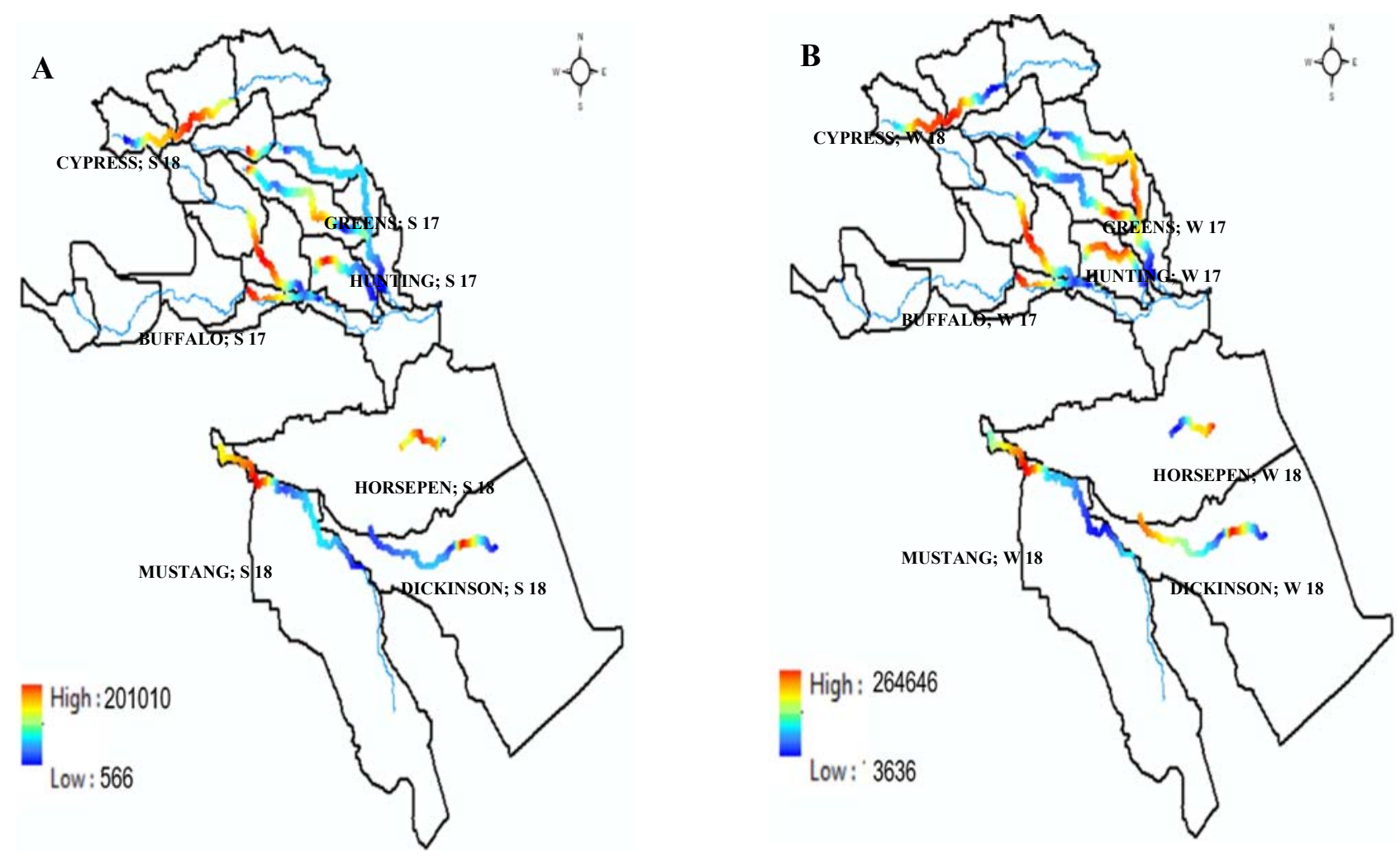

Figure 7. Soil samples for bacterial analysis. Samples were collected across the Greens, Halls, Hunting, White Oak, Buffalo, Cypress Creek, Dickinson, Horsepen and Mustang Bayou during the summer and fall of 2017 and 2018. A. Interpolation map showing the enteric bacteria population over time for summer 2017 and 2018. B. Interpolation map showing the enteric bacteria population over time for winter 2017 and 2018. Arrows compare samples pre- (S17) to post- (W17) Hurricane Harvey. $S=$ summer, $W=$ winter, 17=2017, and $18=2018$.

\section{Discussion}

Houston has experienced three flooding events in a threeyear span, 2015 - 2017 (i.e., the Memorial Day flooding in May of 2015, the tax-day flooding in 2016, and Hurricane Harvey in 2017). We sought to determine microbial loads, identify representative colonies, and assess global population dynamics pre- and post-Harvey. Previous studies have reported bacterial contamination following rainfall $[8,15,26$, $29,35,37]$ at levels high enough to exceed EPA standards. Our findings similarly show that enteric bacterial populations increased following heavy rainfall in several Houston watersheds, likely caused by the redistribution or mobilization of these enteric bacteria pathogens from the watershed to the soil [11, 27]. Contamination of these watersheds can also be caused by a variety of anthropogenic sources such as: proximity to wastewater outfalls, chemical plants, feces from animals, and superfund sites [30]. More specifically, several factors were shown to contribute to high bacterial levels during the wet weather periods such as: wastewater effluent, storm water runoff, treatment facilities, disinfection units, and consistent rain [9-10].

Fong et al. [14] observed that bacterial pollutants can be transported from wastewater outfalls and municipal discharge, through surface and subsurface flow after intense rain events [14]. In agreement with this, we observed bacterial transport from upstream to downstream across some watersheds for
Halls watershed (winter 2017), Greens watershed (summer 2017) and Horsepen watershed (winter 2018) enteric bacteria populations. Heavy rainfall has been linked to disease outbreaks such as typhoid fever, diarrhea, and other waterborne diseases [3]. In that vein, our study isolated and identified opportunistic pathogenic bacteria from the samples analyzed including: $S$. marcenscens, $P$. mendocina, $P$. fulva, and $P$. putida. Further, we identified the Burkholderia spp. in the Halls Bayou ( 2.7-fold higher post-Harvey) in our metagenomic analysis. Burkholderia cepacia is a bona fide human pathogen.

Urban watershed recreationalists are at higher risk of contracting gastro-intestinal diseases and other acute respiratory illness than non-recreationalists $[2,17]$ through kayaking, rowing, and other secondary recreation activities $[2,17]$. Watershed concentrations of enteric bacteria are typically a function of the number of waste-water outfalls, storm drains, and other surface and subsurface runoff discharges. Our study aimed to quantify enteric bacteria and identify pathogenic enteric bacteria associated with waterborne diseases. Interestingly, we observed that enteric bacterial loads were significantly elevated post-Harvey in Halls, Horsepen, and Mustang Bayous compared to their preHarvey 2017 counterparts. Our 2018 data, one year following the Harvey flooding event, similarly revealed significantly elevated enteric counts in the winter compared to the summer (2018), suggesting that fluctuations in enteric counts are most likely a result of temporal change, water flow rates, and 
flooding events.

Ultimately, we observed that watersheds closer to superfund and municipal wastewater treatment facility sites contained higher loads of opportunistic pathogenic bacteria, as we expected. Unexpectedly, however, we found higher enteric bacterial loads in the fall relative to the summer in both 2017 (the year of Hurricane Harvey) and 2018 (one year after the flood). Although we expected some redistribution following the Hurricane Harvey flooding event and potentially higher enteric loads observed in the winter of 2017 as a result, we found higher enteric loads in the winter of 2018 (relative to the summer of 2018) one year later (in a year where there was no flooding event to prompt redistribution. Typically, water flow rates in the Houston watershed are slower in the winter as well as the temperature typically being colder than what mesophilic enteric bacteria prefer $\left(37^{\circ} \mathrm{C}\right)$. Therefore, reasons why enteric loads were found to be higher in Houston watersheds in the winters compared to the summers over the one-year study are still unclear (Figure 7 compare panel B to C). Generally speaking, the rural and suburban Houston watersheds such as Horsepen and Cypress Creek watersheds had lower enteric bacterial loads.

\section{Conclusion}

Enteric bacterial pathogens are major causes of food-borne gastroenteritis in humans and remain an important public health concern worldwide [32, 34]. Indicator bacteria, such as Escherichia coli, have been shown to be present in various watersheds, and several E. coli serotypes (e.g., E. coli O157) present health threats to residents surrounding these watersheds. Our results demonstrate higher enteric counts during the winter in the majority of Houston watersheds evaluated. Serratia marcescens, an opportunistic pathogen and member of the Enterobacteriaceae family, was also prevalent in some of the watersheds. Taken together, our data supports the notion that flooding events may cause redistribution of bacterial pathogens at the species-level; however, phyla-level redistributions are much less likely.

\section{Acknowledgements}

We would like to thank Shishir Shishodia, Hyun-Min Hwang, Daniel Vrinceanu, Jim Briggs, Titilope Bukunmi, and Shari Galvin for their valuable insights and comments. This work was supported by the National Science Foundation (NSF) HRD-1345173, HRD-1400962, and HRD-1622993 and the Department of Education Tittle III award P031B090216. The authors declare there are no conflicts of interest.

\section{References}

[1] Ahmed, W., Hamilton, K., Toze, S., Cook, S., \& Page, D. (2019). A review on microbial contaminants in storm water runoff and outfalls: Potential health risks and mitigation strategies. The Science of the total environment, 692, 13041321. https://doi.org/10.1016/j.scitotenv.2019.07.055.
[2] Arnone, R. D., \& Perdek Walling, J. (2007). Waterborne pathogens in urban watersheds. Journal of Water and Health, $5(1), 149-162$.

[3] Auld, H., MacIver, D., \& Klaassen, J. (2004). Heavy rainfall and waterborne disease outbreaks: the Walkerton example. Journal of Toxicology and Environmental Health, Part A, 67 (20-22), 1879-1887.

[4] Barberán, A., Bates, S. T., Casamayor, E. O., \& Fierer, N. (2012). Using network analysis to explore co-occurrence patterns in soil microbial communities. The ISME journal, 6 (2), 343-351.

[5] Brinkmeyer, R., Amon, R. M., Schwarz, J. R., Saxton, T., Roberts, D., Harrison, S. \& Duan, S. (2015). Distribution and persistence of Escherichia coli and Enterococci in stream bed and bank sediments from two urban streams in Houston, TX. Science of the Total Environment, 502, 650-658.

[6] Çelebi, A., Şengörür, B., \& Kløve, B. (2014). Human health risk assessment of dissolved metals in groundwater and surface waters in the Melen watershed, Turkey. Journal of Environmental Science and Health, Part A, 49 (2), 153-161.

[7] Chellam, S., Sharma, R. R., Shetty, G. R., \& Wei, Y. (2008). Nanofiltration of pretreated Lake Houston water: disinfection by-product speciation, relationships, and control. Separation and Purification Technology, 64 (2), 160-169.

[8] Chu, Y., Salles, C., Tournoud, M. G., Got, P., Troussellier, M., Rodier, C., \& Caro, A. (2011). Faecal bacterial loads during flood events in Northwestern Mediterranean coastal rivers. Journal of Hydrology, 405 (3-4), 501-511.

[9] Desai, A. M., Rifai, H., Helfer, E., Moreno, N., \& Stein, R. (2010). Statistical investigations into indicator bacteria concentrations in Houston metropolitan watersheds. Water Environment Research, 82 (4), 302-318.

[10] Desai, A. M., \& Rifai, H. S. (2013). Escherichia coli concentrations in urban watersheds exhibit diurnal sag: Implications for water-quality monitoring and assessment. JAWRA Journal of the American Water Resources Association, 49 (4), $766-779$.

[11] Dorner, S. M., Anderson, W. B., Slawson, R. M., Kouwen, N., \& Huck, P. M. (2006). Hydrologic modeling of pathogen fate and transport. Environmental science \& technology, 40 (15), 4746-4753

[12] ESRI. 2014. Arc GIS Desktop-Environmental Systems Research Institute: Release 10.3. Redlands, CA, USA.

[13] Ferris, M. J., Norori, J., Zozaya-Hinchliffe, M., \& Martin, D. H. (2007). Cultivation-independent analysis of changes in bacterial vaginosis flora following metronidazole treatment. Journal of clinical microbiology, 45 (3), 1016-1018. k.

[14] Fong, T. T., Mansfield, L. S., Wilson, D. L., Schwab, D. J., Molloy, S. L., \& Rose, J. B. (2007). Massive microbiological groundwater contamination associated with a waterborne outbreak in Lake Erie, South Bass Island, Ohio. Environmental health perspectives, 115 (6), 856-864.

[15] Gelting, R., Sarisky, J., Selman, C., Otto, C., Higgins, C., Bohan, P. O.,... \& Meehan, P. J. (2005). Use of a systemsbased approach to an environmental health assessment for a waterborne disease outbreak investigation at a snowmobile lodge in Wyoming. International journal of hygiene and environmental health, 208 (1-2), 67-73. 
[16] Goto, D. K., \& Yan, T. (2011). Genotypic diversity of Escherichia coli in the water and soil of tropical watersheds in Hawaii. Appl. Environ. Microbiol., 77 (12), 3988-3997.

[17] Handbook of Texas Online, Robert Wooster, "BAYOU CITY," accessed October 29, 2019, http://www.tshaonline.org/handbook/online/articles/etb01. Uploaded on June 12, 2010. Modified on May 26, 2016. Published by the Texas State Historical Association.

[18] Handbook of Texas Online, "MUSTANG BAYOU," accessed May 09, 2020, http://www.tshaonline.org/handbook/online/articles/rhm05. Uploaded on June 15, 2010. Published by the Texas State Historical Association.

[19] Harris County Flood Control District HCFCD. (2015). Streambank Stabilization Handbook: A Guide for harris county Landowners. Retrieved from https://texasriparian.org/wpcontent/uploads/2013/02/HCFCD-Streambank-StabilizationHandbook.pdf.

[20] Harris County Flood Control District HCFCD. (2020). Buffalo Bayou. Harris County Flood Control District. Retrieved from https://www.hcfcd.org/Find-Your-Watershed/Buffalo-Bayou.

[21] Harris County Flood Control District HCFCD. (2020). Halls Bayou. Harris County Flood Control District. Retrieved from https://www.hcfed.org/Find-Your-Watershed/Halls-Bayou.

[22] Harris County Flood Control District HCFCD. (2020). Hunting Bayou. Harris County Flood Control District. Retrieved from https://www.hcfcd.org/Find-YourWatershed/Hunting-Bayou.

[23] Houston-Galveston Area Council (2002) Regional Land Cover Data. Houston-Galveston Area Council: Houston, Texas, http://www.h-gac. com/rds/land_use/default.aspx.

[24] Houston-Galveston Area Council (2008). Bacteria TMDLs for Halls Bayou Halls Bayou http://www.h-gac.com/watershedbased-plans/documents/houston-metro/houston-metro_11-1008 presentation.pdf.

[25] Houston-Galveston Area Council (2015). How's the Water? H-GAC, Basin Highlights Report. Retrieved from https://www.h-gac.com/clean-riversprogram/documents/2015\%20BHR\%20FINAL_Abridged $\% 20$ Version.pdf.

[26] Islam, M. M., Hofstra, N., \& Islam, M. A. (2017). The impact of environmental variables on faecal indicator bacteria in the Betna river basin, Bangladesh. Environmental Processes, 4 (2), 319-332.

[27] Jean, J. S., Guo, H. R., Chen, S. H., Liu, C. C., Chang, W. T., Yang, Y. J., \& Huang, M. C. (2006). The association between rainfall rate and occurrence of an enterovirus epidemic due to a contaminated well. Journal of applied microbiology, 101 (6), 1224-1231

[28] Jeamsripong, S., Chuanchuen, R., \& Atwill, E. R. (2018). Assessment of Bacterial Accumulation and Environmental Factors in Sentinel Oysters and Estuarine Water Quality from the Phang Nga Estuary Area in Thailand. International journal of environmental research and public health, 15 (9), 1970. https://doi.org/10.3390/ijerph15091970.

[29] Kistemann, T., Claßen, T., Koch, C., Dangendorf, F., Fischeder, R., Gebel, J. \& Exner, M. (2002). Microbial load of drinking water reservoir tributaries during extreme rainfall and runoff. Appl. Environ. Microbiol., 68 (5), 2188-2197.

[30] Lalancette, C., Papineau, I., Payment, P., Dorner, S., Servais, P., Barbeau, B., \& Prévost, M. (2014). Changes in Escherichia coli to Cryptosporidium ratios for various fecal pollution sources and drinking water intakes. Water research, 55, 150-161.

[31] Lee, D. Y., Lee, H., Trevors, J. T., Weir, S. C., Thomas, J. L., \& Habash, M. (2014). Characterization of sources and loadings of fecal pollutants using microbial source tracking assays in urban and rural areas of the Grand River Watershed, Southwestern Ontario. Water research, 53, 123-131.

[32] Lukinmaa, S., NAKARI, U. M., Eklund, M., \& Siitonen, A. (2004). Application of molecular genetic methods in diagnostics and epidemiology of food-borne bacterial pathogens. Apmis, 112 (11-12), 908-929.

[33] Mhuantong, W., Wongwilaiwalin, S., Laothanachareon, T., Eurwilaichitr, L., Tangphatsornruang, S., Boonchayaanant, B. \& Khan, E. (2015). Survey of microbial diversity in flood areas during Thailand 2011 flood crisis using high-throughput tagged amplicon pyrosequencing. PloS one, 10 (5).

[34] Nataro, J. P., \& Kaper, J. B. (1998). Diarrheagenic escherichia coli. Clinical microbiology reviews, 11 (1), 142-201.

[35] Olds, H. T., Corsi, S. R., Dila, D. K., Halmo, K. M., Bootsma, M. J., \& McLellan, S. L. (2018). High levels of sewage contamination released from urban areas after storm events: A quantitative survey with sewage specific bacterial indicators. $\begin{array}{lllll}\text { PLoS medicine, } & 15 & \text { (7), } & \text { e1002614. }\end{array}$ https://doi.org/10.1371/journal.pmed.1002614.

[36] Olivera, F., \& DeFee, B. B. (2007). Urbanization and Its Effect on Runoff in the Whiteoak Bayou Watershed, Texas 1. JAWRA Journal of the American Water Resources Association, 43 (1), 170-182.

[37] O'Neill, S., Adhikari, A. R., Gautam, M. R., \& Acharya, K. (2013). Bacterial contamination due to point and nonpoint source pollution in a rapidly growing urban center in an arid region. Urban Water Journal, 10 (6), 411-421.

[38] Pandey, P. K., Kass, P. H., Soupir, M. L., Biswas, S., \& Singh, V. P. (2014). Contamination of water resources by pathogenic bacteria. AMB Express, 4, 51. https://doi.org/10.1186/s13568014-0051-x.

[39] Pandey, P. K., Soupir, M. L., Haddad, M., \& Rothwell, J. J. (2012). Assessing the impacts of watershed indexes and precipitation on spatial in-stream E. coli concentrations. Ecological indicators, 23, 641-652.

[40] Quigg, A., Broach, L., Denton, W., \& Miranda, R. (2009). Water quality in the Dickinson Bayou watershed (Texas, Gulf of Mexico) and health issues. Marine Pollution Bulletin, 58 (6), 896-904.

[41] Rifai, H. (2007). Total Maximum Daily Loads for Fecal Bacteria in the Dickinson Bayou Final Historical Data Review and Analysis Report Revision http://www.tceq.state.tx.us/compliance/monitoring/water/quali ty/data/08twqi/twqi08.htm Texas Commission on Environmental Quality.

[42] Rogers, G. O., \& Defee Ii, B. B. (2005). Long-term impact of development on a watershed: early indicators of future problems. Landscape and Urban Planning, 73 (2-3), 215-233. 
[43] Sipes, J. L., \& Zeve, M. K. (2012). The Bayous of Houston. Arcadia Publishing.

[44] Sneck-Fahrer, D. A., Milburn, M. S., East, J. W., \& Oden, J. H. (2005). Water-Quality Assessment of Lake Houston near Houston, Texas, 2000-2004 (No. 2005-5241). US Geological Survey.

[45] Stocker, M. D., Rodriguez-Valentin, J. G., Pachepsky, Y. A., \& Shelton, D. R. (2016). Spatial and temporal variation of fecal indicator organisms in two creeks in Beltsville, Maryland. Water Quality Research Journal of Canada, 51 (2), 167-179.

[46] Teague, A., Christian, J., \& Bedient, P. (2013). Radar rainfall application in distributed hydrologic modeling for Cypress Creek watershed, Texas. Journal of Hydrologic Engineering, 18 (2), 219-227.

[47] Texas Coastal Watershed Program. 2008. Land Use Classification GIS layer. Available at www.urban-nature.org.

[48] Texas Commission on Environmental Quality water quality 2018

https://www.tceq.texas.gov/assets/public/waterquality/standar ds/tswqs2018/2018swqs_allsections_nopreamble.pdf. From https://www.tceq.texas.gov/waterquality/standards/2018surface-water-quality-standards.

[49] Thomas, P., Sekhar, A. C., Upreti, R., Mujawar, M. M., \& Pasha, S. S. (2015). Optimization of single plate-serial dilution spotting (SP-SDS) with sample anchoring as an assured method for bacterial and yeast cfu enumeration and single colony isolation from diverse samples. Biotechnology Reports, 8, 45-55.

[50] Tiefenthaler, L. L., Stein, E. D., \& Lyon, G. S. (2009). Fecal indicator bacteria (FIB) levels during dry weather from Southern California reference streams. Environmental monitoring and assessment, 155 (1-4), 477-492.

[51] United States Environmental Protection Agency (USEPA). (2000). "Bacterial indicator tool user's guide." EPA-832-B01-003, Washington, D.C.

[52] U.S. EPA 2012a. Water Quality Standards Handbook: Second Edition. EPA-823-B-12-002; March 2012. Retrieved November $\quad 13, \quad 2012$ from http://water.epa.gov/scitech/swguidance/standards/handbook/i ndex.cfm.

[53] U.S. EPA 2012b. Method 1611: Enterococci in Water by TaqMan ${ }^{\circledR}$ Quantitative Polymerase Chain Reaction (qPCR) Assay. EPA-821-R-12-008. https://www.epa.gov/sites/production/files/201510/documents/rwqc2012.pdf.

[54] U.S. Geological Survey. Geographic Names Phase I data compilation (1976-1981). 31-Dec-1981. Primarily from U.S. Geological Survey 1:24,000-scale topographic maps (or 1:25K, Puerto Rico 1:20K) and from U.S. Board on Geographic Names files. In some instances, from 1:62,500 scale or 1:250,000 scale maps.

[55] Van Loon, A. F., Ploum, S. W., Parajka, J., Fleig, A. K., Garnier, E., Laaha, G., \& Van Lanen, H. A. J. (2015). Hydrological drought types in cold climates: quantitative analysis of causing factors and qualitative survey of impacts. Hydrology and Earth System Sciences, 19 (4), 1993.

[56] Wilkes, G., Brassard, J., Edge, T. A., Gannon, V., Gottschall, N., Jokinen, C. C., Jones, T. H., Khan, I. U., Marti, R., Sunohara, M. D., Topp, E., \& Lapen, D. R. (2014). Long-term monitoring of waterborne pathogens and microbial source tracking markers in paired agricultural watersheds under controlled and conventional tile drainage management. Applied and environmental microbiology, 80 (12), 3708-3720. https://doi.org/10.1128/AEM.00254-14.

[57] Whitman, R. L., Nevers, M. B., \& Byappanahalli, M. N. (2006). Examination of the watershed-wide distribution of Escherichia coli along Southern Lake Michigan: an integrated approach. Applied and environmental microbiology, 72 (11), 7301-7310. https://doi.org/10.1128/AEM.00454-06.

[58] Wu, C. H., Sercu, B., Van de Werfhorst, L. C., Wong, J., DeSantis, T. Z., Brodie, E. L., Hazen, T. C., Holden, P. A., \& Andersen, G. L. (2010). Characterization of coastal urban watershed bacterial communities leads to alternative community-based indicators. PloS one, 5 (6), e11285. https://doi.org/10.1371/journal.pone.0011285.

[59] Wu, J., Rees, P., \& Dorner, S. (2011). Variability of E. coli density and sources in an urban watershed. Journal of water and health, 9 (1), 94-106. 